\title{
POTENTIAL OF FLOW CYTOMETRY IN SEX DETERMINATION AND IN VITRO MICROPROPAGATION OF LAURUS NOBILIS L.
}

\author{
ROYANDAZAGH, D. S. \\ Department of Agricultural Biotechnology, Faculty of Agriculture, Tekirdağ Namik Kemal \\ University, Degirmenaltı Campus 59030 / Suleymanpasa-Tekirdag, Turkey \\ e-mail: sdaneshvar@nku.edu.tr; phone:00905314318608
}

(Received 31 Jan 2019; accepted 21 ${ }^{\text {st }}$ Mar 2019)

\begin{abstract}
Perennial bay laurel (Laurus nobilis L.) is a dioecious economic plant. Its leaves and fruits are considered as important non-wood forest products that are used in food, pharmaceutical, and cosmetic industries. However, it is not possible to distinguish males and females at an early age and this can hinder its multiplication in a planned way. The aim of the present study is to determine the sex of bay laurel at an early stage by analyzing the nuclear DNA (Deoxyribonucleic acid) contents using flow cytometry. The findings of the study showed that the male DNA content is $\geq 7.95 \pm 0.13 \mathrm{pg}$ and the female nuclear DNA content is $\leq 7.84 \pm 0.10 \mathrm{pg}$. After sex determination, female green axillary buds were cultured on MS (Murashige and Skoog) medium containing different combinations including BAP (6-Benzylaminopurine), NAA (1-Naphthaleneacetic acid) and GA3 (Gibberellic acid) for 42 days to induce micropropagation of the buds. The results indicated $100 \%$ shoot regeneration with $2.5 \pm 0.85$ shoots per explant on MS medium containing 6.6 $\mu \mathrm{M}$ BAP, 5.4 $\mu \mathrm{M}$ NAA, and $0.6 \mu \mathrm{M}$ GA3. Each randomly selected 45 female shoots were rooted on MS medium containing $4.90 \mu \mathrm{M}$ IBA (Indole-3-butyric acid) for 12 weeks. Only 16 among them induced roots. However, 13 female plantlets, upon their transfer to pots, showed continuing viability and successful acclimatization to external conditions. Distinguishing sex of bay laurel plants at an early age and establishment of a rapid propagation protocol could offer a significant benefit in breeding and plant production.
\end{abstract}

Keywords: bay laurel, Laurus nobilis L., DNA content, dioecious plant, micropropagation, acclimatization, sex determination, adult plants

\section{Introduction}

The family of Lauraceae has 45 genera and 2850 known species worldwide (Maarten and Christenhusz, 2016). Different ploidy levels have been described, in Laurus with tetraploidy $(2 \mathrm{n}=4 \mathrm{x}=48)$, as the most frequent karyotype (Ehrendorfer et al., 1968). Bay laurel has spread over Tropical Asia, America, Africa, and Mediterranean countries (Darlington and Wylie, 1955). It can resist temperatures as low as $-15^{\circ} \mathrm{C}$ in natural distribution areas (Lanzara, 1978). The hairless dark green leaves and black fruits are highly aromatic due to the presence of oil-filled cavities (Villar, 1986). Both fruits and leaves contain different types of essential oils with different quantities in them. These contain $25-30 \%$ green, aromatic oil consisting of a variety of fatty acids, including glycerides of acetic, oleic, linoleic, stearic, palmitic, myristic, and lauric acids, and free acetic acid oil (Panza et al., 2011). Both, its fruits and leaves are significantly important in pharmaceutical, food and cosmetics industries (Ercan, 1983). The dried leaves exclusively used to flavor foods as they produce about $1.3 \%$ essential oils containing $45 \%$ eucalyptol, $12 \%$ terpenes, $8-12 \%$ terpinyl acetate, $3-4 \%$ sesquiterpenes, $3 \%$ methyleugenol, and other $\alpha$ - and $\beta$-pinenes, phellandrene, linalool, geraniol, and terpineol. Their concentrations are inconsistent and differ with the antagonistic stage of plant growth. Generally, the highest oil percentage is obtained from dried leaves during mid-summer harvest (Tanriverdi et al., 1993; Konukçu, 2001; Kilic et al., 2004). Therefore, early identification of the plants is of significant importance. The strategies 
to multiply male and female plants have significant importance and could be planned at an advanced stage of growth and with a purposeful and positive contribution to the economy of Turkey (Ercan, 1983). Anatolia and Balkans are considered as the origin of bay laurel. Nowadays, it grows in all of the Mediterranean countries (Algeria, Turkey, Italy, Greece, Morocco, Portugal, Spain, Albania, Romania and in the Greek islands in the Aegean Sea, on the eastern coasts of Libya, the western part of Syria, Israel, Palestine), Northern Europe (Belgium, France), The Black Sea coast of Russia, Georgia, Crimea, and Mexico at altitude of 600-800 $\mathrm{m}$ above sea level in temperate regions (Göker and Acar, 1983; Demir et al., 2004). The bay laurel Essential Oils (eugenol, cineol and geraniol), account for the distinctive spicy aroma and are extracted from its fruits and leaves (Konukçu, 2001). It is also considered in manufacturing perfumes and soap in many parts of the world (Tanrıverdi et al., 1993; Dhifi et al., 2018). Phenotypic sex determination is practically not possible during the early stages of the development of dioecious plants. It is possible to determine the ploidy level of plants by using flow cytometry for measuring the amount of nuclear DNA in plants. The data Information about genome size is a very important factor in determining the biodiversity of a large number of biological fields (Zonneveld, 2005). The flow cytometry could be used for plants' early sex determination studies. The identification and sex determination of dioecious plants could provide a significant advantage in production, multiplication, and breeding of plants (Bennett and Smith, 1976; Tuna, 2016). Therefore, the purpose of this study is to develop a protocol for sex determination of bay laurel seedling after their germination and establish micropropagation protocol in female sapling through axillary stem buds.

\section{Materials and Methods}

\section{Plant material}

The fresh bay laurel seeds were purchased from Yalova seed vendor in the open market. The number of chromosomes was determined as 48 in different studies. These seeds were stored at room temperature for 2 weeks and were, then, germinated at $+4^{\circ} \mathrm{C}$ for 6 weeks. All treatments of sex determination, regeneration and rooting experiments were carried out in Department of Agricultural Biotechnology and Department of filed crop Tekirdağ Namik Kemal University, Tekirdag, Turkey.

\section{Sterilization and germination}

The seeds were first rinsed with $2 \%$ solution of Tween 20 , followed by sterilizing with 20,40,60,80, and 100 percent commercial bleach (containing active $5 \% \mathrm{NaOCl}-$ Ace, Turkey), and ensued by $4 \times 4$ times rinsing with bidistillated and sterilized water. Seeds with 100 less pericarp were, then, germinated on MS medium (Murashige and Skoog, 1962) and supplemented with $30 \mathrm{~g} / \mathrm{l}$ sucrose in glass tubes (1 seed/test tube) of adjusted $\mathrm{pH}$ to $5.7 \pm 0.1$ For germination, these seeds were cultured in Sony versatile environmental chambers under $24 \pm 1{ }^{\circ} \mathrm{C}$ using 16 hours' light/ 8 hours' dark photoperiod.

After seed germination, the leaf samples of in vitro germinated plants were taken for sex determination analysis by flow cytometry. Adult male and female plants were also analyzed for the purpose of comparison along the freshly germinated seedlings for 
comparison purpose and validate the results. The regeneration studies were initiated by taking green shoot buds from respective female seedlings.

\section{Flow Cytometry and Sex Determination}

Fully developed bay laurel leaf samples were taken from 2-month-old seedlings and were cultivated under in vitro conditions; barley (Hordeum vulgare) $2 \mathrm{C}$ DNA $=10.65 \mathrm{pg}$ was used for estimation of genome size in Laurus nobilis in flow cytometry with the fluorescing DNA stain 4',6-diamidino-2-phenylindole (DAPI) as per manufacturer's instructions (Thermofisher Scientific Waltham, Massachusetts USA). The nuclear DNA quantification studies were set up using 3 replications.

\section{Estimation of nuclear DNA content}

The 10-15 mg samples were taken from the leaf tissues of barley grown by the standard in vivo and leaf tissues of bay laurel germinated by in vitro conditions; they were cultured in Petri dishes on MS medium afterwards. By adding $1 \mathrm{ml}$ of A stock solution $\left(20 \mathrm{ml} \mathrm{MgSO}_{4}\right.$ buffer, $20 \mathrm{mg}$ Dithiothreitol, $500 \mu \mathrm{l}$ DAPI stock, $550 \mu \mathrm{l}$ TritonX-100) to the petri dish (Arumuganathan and Earle, 1991; Noirot et al., 2002), the plant tissues were decomposed with razor blades until they were crumbled away in the solution. The solution was filtered $(30-33 \mu \mathrm{m})$ and followed by micro-centrifuging. The Supernatant, formed in the bottom of the micro-centrifuge tube, was dissolved in $400 \mu \mathrm{l}$ B solution ( $5 \mathrm{ml}$ solution A, $10 \mu \mathrm{l}$ RNAse and DNAse free). Thereafter, the prepared samples were incubated in $5 \mathrm{ml}$ glass tubes for 15 minutes at $37^{\circ} \mathrm{C}$ temperature. The samples were analyzed by flow cytometry (Partec) device (Tuna et al., 2001; Savas Tuna et al., 2017). The absolute DNA content of 58 germinated bay laurel seedlings was calculated by using the values of the fluorescence intensities of the M1 peaks at the selected standard and the following formula, as a picogram (Zonneveld et al., 2005; Aydın Akbudak et al., 2018), was used for this purpose:

$$
\text { Sample DNA content } 2 \mathrm{C}=\frac{\text { mean of sample peak }(\mathrm{M} 1)}{\text { mean of sample peak }\left(\mathrm{Ml}_{\mathrm{i}}\right)} * \text { Standard DNA content } 2 \mathrm{C} \text { (Eq.1) }
$$

The data used in the formula was obtained from flow cytometry analyses. The separation of the male and female plant, by measuring their DNA content quantities, were conducted and the results were later compared with the results of Parlar (2017).

\section{In vitro Micropropagation}

The plant is difficult to multiply due to high oxidation of phenolic compounds (25-30\% essential oil in female plants compared to males with $1.3 \%$ essential oils only. The idea was to use female plants that are more prone to necrosis and compared to male plants with lesser concentrations of essential oils and phenolic compounds. Therefore, axillary bud explants from the female seedlings, grown under in vitro conditions, were cultured on MS medium containing different combinations and concentrations of BAP, NAA and GA3.

\section{Rooting and acclimatization}

The growing shoots were re-cultured on MS medium containing 4.4 $\mu \mathrm{M}$ BAP. The 45 regenerating shoots were rooted in MS medium containing 2.24, 4.90 and $7.35 \mu \mathrm{M}$ 
IBA in sterile glass jars. At this stage, the bay laurel seedlings $(5-10 \mathrm{~cm}$ in length) were washed with tap water without harming the leaves and roots. These were transferred to sterilized peat moist in $500 \mathrm{ml}$ paper cups. The pots were covered with transparent polythene bags and were left to grow in an environmental chamber. The bags were gradually perforated at the end of the second week to increase air circulation and to reduce the humidity $40-50 \%$ at $+25 \pm 2^{\circ} \mathrm{C}$ (Dewir et al., 2015). This was done to adapt the plants to external conditions. The polythene bags were completely removed later and the plants were left to grow and harden in the environmental chamber. These plants were watered with liquid MS medium once in a month.

\section{Statistical analysis of regeneration studies}

All treatments of regeneration and rooting experiments used 15 explants (unless otherwise mentioned) which were divided equally into three replicates containing 5 explants each ( 3 replications $\times 5$ explants $=15$ explants); treatments were repeated twice afterwards. Statistical analysis of the data was carried out by using IBM SPSS18 (Statistical Package for the Social Sciences) computer software. The means were separated by using the Duncans Multiple Range Test and the percentage values were subjected to "arcsine transformation", before carrying out the statistical analysis (Snedecor and Cochran, 1982).

\section{Results}

\section{Surface Sterilization and Germination of bay laurel}

Out of different commercial bleach concentrations used for sterilization of bay laurel seeds, 60-100\% commercial bleach concentration showed the most optimum results with $80 \%$ seed germination and development of no fungus or bacterial contamination of the seeds. However, the $80-100 \%$ commercial bleach concentration had negative impacts on the growth and development of seeds. The results are given in Table 1.

Table1. Effects of different concentrations of Sodium of Sodium hypochlorite (NaOCl) on contamination and germination of with pericarp and without pericarp seed of Laurus nobilis $L$.

\begin{tabular}{c|c|c}
\hline $\begin{array}{c}\text { Concentration of in percentage Sodium } \\
\text { hypochlorite (NaOCl) (\%) for sterilization of } \\
\text { Seeds with pericarp }\end{array}$ & $\begin{array}{c}\text { Contamination } \\
\text { percentage (\%)Seeds } \\
\text { with pericarp }\end{array}$ & $\begin{array}{c}\text { Germination } \\
\text { percentage (\%)Seeds with } \\
\text { pericarp }\end{array}$ \\
\hline 100 & $26.5 \pm 0.0 \mathrm{~b}$ & $0.0 \pm 0.0 \mathrm{c}$ \\
80 & $39.2 \pm 0.0 \mathrm{c}$ & $0.0 \pm 0.0 \mathrm{c}$ \\
60 & $50.7 \pm 0.0 \mathrm{~d}$ & $0.0 \pm 0.0 \mathrm{c}$ \\
40 & $63.4 \pm 0.0 \mathrm{e}$ & $0.0 \pm 0.0 \mathrm{c}$ \\
20 & $90.0 \pm 0.0 \mathrm{f}$ & $0.0 \pm 0.0 \mathrm{c}$ \\
0 (control) & $90.0 \pm 0.0 \mathrm{f}$ & $0.0 \pm 0.0 \mathrm{c}$ \\
\hline Without pericarp & Without pericarp & Without pericarp \\
\hline 100 & $0.0 \pm 0.0 \mathrm{a}$ & $22.7 \pm 10 \mathrm{c}$ \\
$\mathbf{8 0}$ & $\mathbf{0 . 0} \mathbf{0 . 0 a}$ & $\mathbf{7 1 . 5} \pm \mathbf{2 0 a}$ \\
\hline 40 & $0.0 \pm 0.0 \mathrm{a}$ & $63.4 \pm 28 \mathrm{a}$ \\
20 & $30.0 \pm 10 \mathrm{~b}$ & $45.0 \pm 11 \mathrm{~b}$ \\
0 (control) & $77.0 \pm 10 \mathrm{f}$ & $12.9 \pm 5.7 \mathrm{c}$ \\
\hline
\end{tabular}

Means shown by different small letters in a single column are statistically different at 0.01 level of significance using Duncans multiple 
The contamination percentage had a range of 26.57-90\%, however, the concentration was decreased by each increase in the commercial concentration of commercial bleach on seeds with pericarps. No seed germination was noted irrespective of the commercial bleach concentration treatment and control treatment. The contamination percentage had a range of $0.00-77.08 \%$ and decreased with each increase in the concentration of commercial bleach on seeds without pericarps. No contamination was noted on seeds treated with 60-100\% commercial bleach. The study indicates seed sterilization and their germination behavior with and without pericarps. The contamination rate was lower and the germination percentage was higher on the seeds. On pericarps removal, germination percentage had to be ranged between $0-80 \%$.

\section{Flow cytometry and sex determination}

In seeds without a pericarp, $60 \% \mathrm{NaOCl}$ concentration was applied and 58 stable bay laurel seeds were germinated. The DNA content and average of bay laurel was calculated by in flow cytometry with the fluorescing DNA stain 4',6-diamidino-2phenylindole (DAPI) analysis with Partec device on the Fully developed bay laurel leaf samples of these seedlings The obtained DNA content of 58 bay laurel seedlings and 50 samples each from known male and female plants were taken as control treatment and were, then, compared with the studies. The number of chromosome $2 n=2 x=48$ in the female and male plants, in the average DNA content of the plant, showed a 0.05 difference between male and female plants. It was observed that the male DNA contents of the male and female plant were slightly, a small margin of $0.11 \mathrm{pg}$, higher than the female plants. According to Parlar (2017), determined DNA contents of 84 male and female plants, were separated into independent groups by being subjected to t-test analysis, whereby the DNA content of the female plants was reported as $7.84 \pm 0.10 \mathrm{pg}$ and the DNA content of the male plants was $7.95 \pm 0.13 \mathrm{pg}$. The results of this study showed that the DNA content of bay laurel, ranged between 7.04-8.14 pg, was divided into two groups; the male plants had nuclear DNA content of $\geq 7.95 \pm 0.13 \mathrm{pg}$ and the female ones had nuclear DNA content of $\leq 7.84 \pm 0.10 \mathrm{pg}$. The result of this study showed that 43 out of the 58 seedlings were females and 16 of them were males (Fig. 1). The DNA content of the previously known males of $\geq 7.95 \pm 0.13 \mathrm{pg}$ and females of $\leqslant$ $7.84 \pm 0.10 \mathrm{pg}$ also showed the same threshold level in their DNA contents.
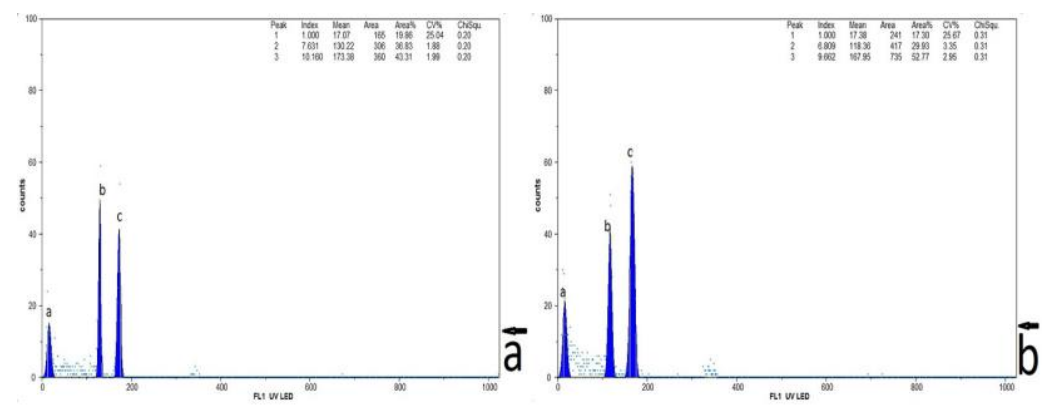

Figure 1. Comparative schematic representation of Laurus nobilis histograms showing flow cytometry analysis of isolated nuclei of male and female plants (a) peak a-fragmented nuclei, chromosomes, plastids and other organeller, peak $b$ - M1, L. nobilis, male seedlings DNA content of $7.99 \mathrm{pg}$, peak c- $M 2$ nuclear DNA content of Barley (H. vulgare) (b) peak a-fragmented nuclei, chromosomes, plastids and other organeller, peak $b$ - MI, female seedling nuclear DNA content of $7.51 \mathrm{pg}$, peak of L. nobilis, peak c-M2 nuclear DNA content of Barley (Hordeum vulgare) 


\section{In vitro Micropropagation}

The axillary bud explants, obtained from 2-month-old female bay laurel seedlings, germinated under in vitro conditions using by flow cytometry, were transferred to MS medium containing different doses and combinations of BAP, NAA, and GA3. The shoot regeneration was noted on all shoot buds irrespective of their concentrations and combinations of BAP+NAA+GA3. The best shoot regeneration was noted on MS medium as containing $6.6 \mu \mathrm{M}$ BAP $+5.4 \mu \mathrm{M}$ NAA $+0.6 \mu \mathrm{M}$ GA3 (Fig. $2 a, b$ ).

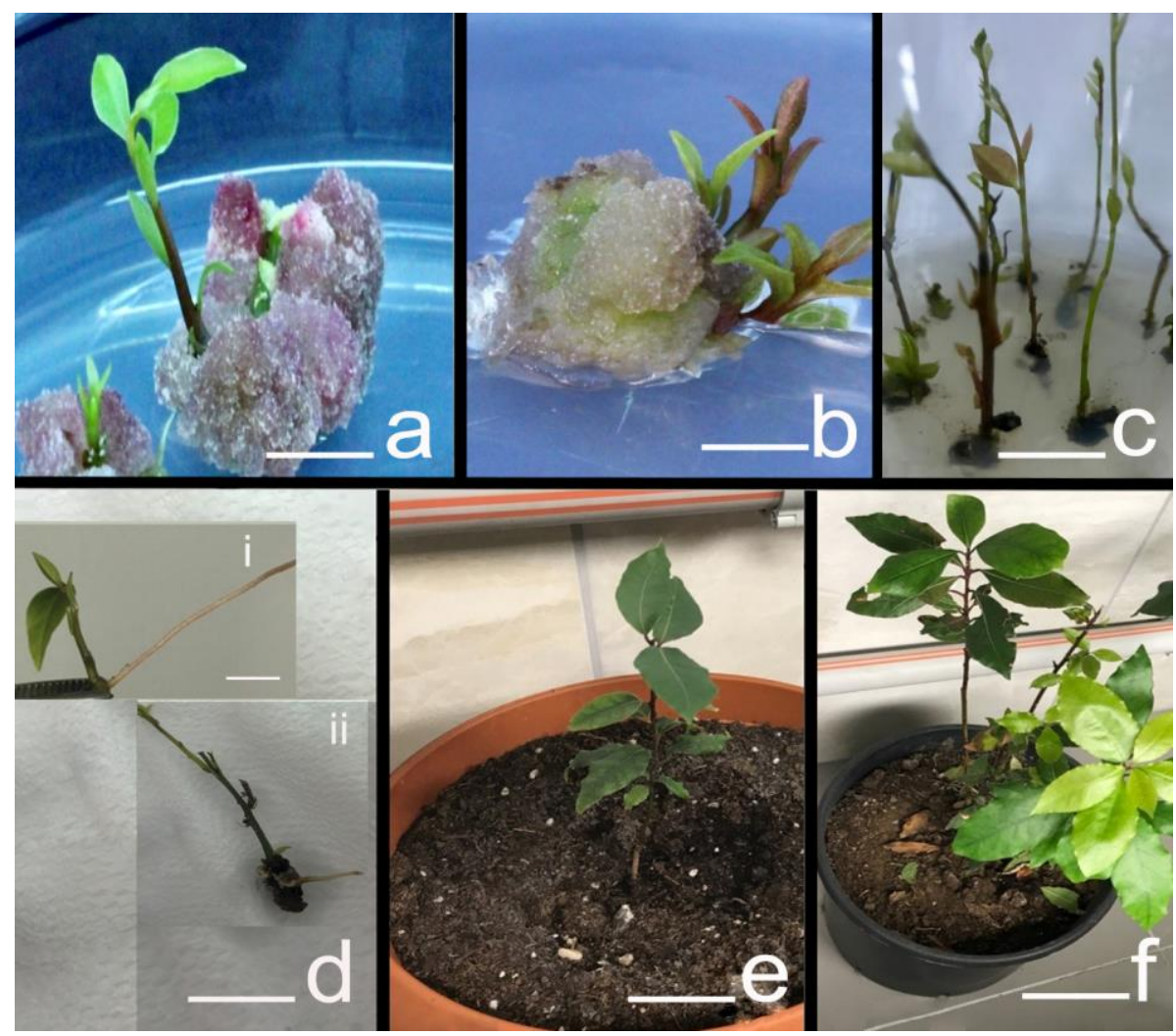

Figure 2. In vitro regeneration from female shoot buds on axillary bud explants of $L$. nobilis $(a))$ induction of shoots on axillary buds induced calli of female using $6.6 \mu M B A P+5.4 \mu M N A A+$ $0.6 \mu \mathrm{M} \mathrm{GA}_{3}(\mathrm{c})$ rooting of in vitro regenerated shoots using $4.90 \mu \mathrm{M} \mathrm{IBA}(d)$ rooted shoots of female shoots (e) the saplings transferred to pots after 3 months in environmental chamber $(d)$ the saplings ready for transfer to fields with profuse growth of leaves. bar in frame $(a, b) 1.1 \mathrm{~cm}$ (c) $1.25 \mathrm{~cm}(d-i) 1 \mathrm{~cm}(d-i i) 1.2 \mathrm{~cm}(e) 1.5 \mathrm{~cm}(f) 2 \mathrm{~cm}$

After 42 days $(2 \times$ subcultures $)$, the data were collected by testing the growth of the regenerating female shoots. The shoots regenerating on the explants, after their excision as single female shoots, were transferred to MS medium for 28 days. The Analysis of variance results showed that shoot regeneration percentage (\%), the average number of shoots per explant, and their shoot length showed significant differences among treatment means. The maximum number of shoot induction per explant was obtained as $2.5 \pm 0.85$ on MS nutrient medium containing $6.6 \mu \mathrm{M} \mathrm{BAP}+5.4 \mu \mathrm{M} \mathrm{NAA}+0.6 \mu \mathrm{M}$ GA3. In terms of shoot percentage, the best results were obtained on the MS medium containing $8.8 \mu \mathrm{M}$ BAP $+2.7 \mu \mathrm{M}$ NAA $+0.6 \mu \mathrm{M}$ GA3. The longest shoots were obtained on MS medium containing $6.6 \mu \mathrm{M}$ BAP $+5.4 \mu \mathrm{M}$ NAA + $0.6 \mu \mathrm{M}$ GA3 (Table 2). 
Table 2. Effects of different concentrations of NAA, BAP and GA3 on regeneration of shoots after 42 days of culture from axillary buds of Laurus nobilis

\begin{tabular}{|c|c|c|c|c|c|}
\hline \multicolumn{3}{|c|}{ Medium $(\mu \mathrm{M})$} & \multirow[t]{2}{*}{$\begin{array}{c}\text { Shoot regeneration } \\
\text { percentage }(\%) * *\end{array}$} & \multirow[t]{2}{*}{$\begin{array}{c}\text { Number of shoots per } \\
\text { explant* }\end{array}$} & \multirow[t]{2}{*}{$\begin{array}{c}\text { Shoot lengtl } \\
(\mathbf{c m})^{*}\end{array}$} \\
\hline BAP & NAA & GA3 & & & \\
\hline 4.4 & 2.7 & 0.6 & $60.0 \pm 26.61 \mathrm{abc}$ & $1.0 \pm 0.0 \mathrm{~b}$ & $0.2 \pm 0,0 \mathrm{bc}$ \\
\hline 4.4 & 5.4 & 0.6 & $26.5 \pm 0.0 \mathrm{c}$ & $1.0 \pm 0.0 \mathrm{~b}$ & $0.2 \pm 0,1 \mathrm{bc}$ \\
\hline 4.4 & 8.1 & 0.6 & $21.9 \pm 20.0 \mathrm{c}$ & $0.6 \pm 0.5 b$ & $0.1 \pm 0,0 \mathrm{c}$ \\
\hline 6.6 & 0.5 & 0.6 & $35.0 \pm 7.3 \mathrm{bc}$ & $1.2 \pm 0.2 \mathrm{~b}$ & $0.3 \pm 0.2 \mathrm{abc}$ \\
\hline 6.6 & 5.4 & 0.6 & $54.9 \pm 7.3 \mathrm{abc}$ & $2.5 \pm 0.8 \mathrm{a} \longleftarrow$ & $0.4 \pm 0,2 \mathrm{a}$ \\
\hline 6.6 & 8.1 & 0.6 & $30.0 \pm 26.6 \mathrm{bc}$ & $0.6 \pm 0.5 b$ & $0.1 \pm 0,0 \mathrm{c}$ \\
\hline 8.8 & 2.7 & 0.6 & $76.9 \pm 22.6 \mathrm{a}<$ & $1.3 \pm 0.4 \mathrm{~b}$ & $0.3 \pm 0,1 \mathrm{abc}$ \\
\hline 8.8 & 5.4 & 0.6 & $68.8 \pm 36.6 \mathrm{ab}$ & $1.2 \pm 0.2 b$ & $0.2 \pm 0,1 \mathrm{bc}$ \\
\hline 8.8 & 8.1 & 0.6 & $71.1 \pm 15.3 \mathrm{ab}$ & $1.1 \pm 0.1 \mathrm{~b}$ & $0.2 \pm 0,0 \mathrm{bc}$ \\
\hline \multicolumn{3}{|c|}{ Control (MS medium) } & $0.0 \pm 0.0$ & $0.0 \pm 0.0$ & $0.0 \pm 0.0$ \\
\hline
\end{tabular}

*Means shown by different small letters in a single column are statistically different at 0.05 level of significance using Duncans multiple range test

**Means shown by different small letters in a single column are statistically different at 0.01 level of significance using Duncans multiple range test

\section{Rooting and acclimatization of bay laurel shoots}

In vitro regenerated female shoots of 3-5 $\mathrm{cm}$ long that was rooted on $4.90 \mu \mathrm{M}$ IBA (Fig. 2c). The first indications of rooting appeared after 4 weeks on MS medium containing $4.90 \mu \mathrm{M}$ IBA. The increase in the number of roots was very evident after 12 weeks, with the highest rooting on MS medium containing $4.90 \mu \mathrm{M}$ IBA (Fig. $2 d-i$ and $2 d-i i)$ on female shoots. Out of 45 female shoots used for rooting only 16/90 (17.77\%) of them induced roots. The other concentrations of IBA were not suitable for rooting compared with this concentration. $2.24 \mu \mathrm{M}$ IBA was non-inducing and $7.35 \mu \mathrm{M}$ IBA showed necrosis and burning on the treated shoots. The number of roots increased when the rooted plantlets were cultured on MS medium. Prolonged culture of shoots on 4.90 $\mu \mathrm{M}$ IBA containing medium tended to induce callus formation that had negative effects on root growth and development.

Out of 16 rooted female plantlets, as mentioned above, only 13 could be acclimatized to external conditions after their transfer to pots (Fig. 2e). After the hardening period of 3 months in the environmental chamber, these female plants were ready for transfer to the fields (Fig. 2f).

\section{Discussion}

Sex determination cannot be ensured phenotypically at the first stage of the development of dioecious plants like bay laurel, in general. The literature reports no studies relating to sex determination in bay laurel at the seedling stage with highly limited in vitro micropropagation studies. It is highly significant to determine the sex and production protocols in bay laurel for the establishment of planned breeding and production programs.

The elimination of micro-organisms from the tissues has great importance in in vitro cultures of plants. During seed or tissue sterilization, surface contact of $\mathrm{NaOCl}$ must be adjusted to the level that it doesn't have any hazardous effect. This depends on the 
careful adjustment of the concentration of disinfectant, duration of application, and the surrounding temperature. The researchers report high sterilization and germination of seeds without pericarps. The contamination rate was lower and the germination percentage was higher on the seeds if the pericarps were not removed. It was also found that diluted $30 \%$ commercial bleach $(5 \% \mathrm{NaOCl})$ is suitable as a sterilizing agent of bay laurel seeds without pericarps. Additionally, that high-frequency of seed germination was highly affected by seed health during sterilization. The optimization of appropriate seed sterilization procedure is a prerequisite for carrying out any tissue culture experiment. The high (40-100\% concentration) dose of commercial bleach was hazardous to the health of the seeds and resulted in a reduction of seed germination. The results of the study are in agreement with previous studies (Sari et al., 2006; Şenyay, 2008; Erkmen, 2009; Chaari Rkhis et al., 2011; Cavusoglu et al., 2014). These studies suggest that sodium hypochlorite exhibits a broad spectrum of anti-microbial activity and effectively disinfect or inactivate bacterial, fungal, and viral organisms adhering to the surface of explants. Contrary to Chourfi et al. (2014), who has reported germination of laurel seeds using kinetin and IAA (indole acetic acid), NAA on WMP (woody plant medium), this study did not need any phytohormonal treatment to germinate seeds.

\section{Sex determination}

DNA content was determined by using flow cytometry method on the leaf samples taken from bay laurel seedlings germinated under in vitro conditions and as a result of this study, it was determined that DNA content of bay laurel changes between 7.04 to 8.14 and it was showed that 43 out of the 58 seedlings were female and 16 of them were male. DNA content of male and female plant are not significantly different in statistical terms but is different numerically. The results were confirmed by finding the amount of DNA on adult male and female plants. Therefore, it is assumed that the method of determining sex would work. Sex determination was performed by comparing the DNA content of the plant following (Parlar, 2017). Doležel and Göhde (1995) have confirmed the sex determination of chalk plants by using flow cytometry. They used young leaves of two different chalk plants (Melandrium. album and Melandrium. rumrum), and noted that the nuclear DNA content of cells of female plants was lower compared to the DNA content in the cells of male plants. The nuclear DNA content of male and female plants differed at arate of $3.7 \%$ (Costich et al., 1991). It was shown that the DNA content of male Silene latifolia plants was larger compared to the DNA content of female plants. Furthermore, the researchers reported a difference in AT/GC contents of the males and females. Whereas Vagera et al. (1994) have shown androgenesis under in vitro conditions, by using ripe microspores of $M$. album. Supermales were crossed with normal female plants under in vitro conditions, to obtain female plants. Flow cytometry analysis was positively used for the determination of sex and the ploidy level. However, the researcher (Cepeda-Cornejo et al., 2012) did not find any significant differences between male and female individuals in terms of DNA during content sex analysis study of four Chamaedorea palm species.

\section{Micropropagation}

Micropropagation studies on axillary buds showed the induction of an average number of shoots per explant. The best regeneration was noted on MS medium containing $8.8 \mu \mathrm{M}$ BAP, $2.7 \mu \mathrm{M}$ NAA, and $0.6 \mu \mathrm{M}$ GA3. The results are supported by the findings of Stanica et al. (1992), who used axillary buds of one-year bay laurel, 
lateral shoots of 2-3 cm in length, apical meristems, and 1 node fragments of developing shoots as explants. They took explants' starting material at 6 different times between February and May and regenerated them on MS medium containing $0.01 \mathrm{mg} / \mathrm{l} \mathrm{NAA} \mathrm{+}$ $0.3 \mathrm{mg} / \mathrm{L} \mathrm{BA}+250 \mathrm{mg} / \mathrm{L}$ Ascorbic acid $+1 \mathrm{mg} / \mathrm{L} \mathrm{MS}$ medium containing adenine sulphate, and DKW nutrient media containing $0.2 \mathrm{mg} / \mathrm{L} \mathrm{IBA}+1 \mathrm{mg} / \mathrm{L} \mathrm{BA}$. They found that MS medium showed induction of callus at the rate of $62 \%$. This was ensued by shoot formation on DKW medium. On the contrary, Souayah et al. (2002) reported that the best shoot development in axillary buds occurred on $1 / 3 \times$ MS medium containing $1 \mathrm{mg} / \mathrm{L} \mathrm{BAP}+1 \mathrm{mg} / \mathrm{L} \mathrm{GA} 3$. Callus development was observed in medium containing BAP and NAA; it was reported that the addition of activated coal to nutrient medium enhanced the development of root and callus. Cobo et al. (2019) reported that the significantly higher numbers of shoots per bud in mortio (Vaccinium floribundum Kunth) were observed on mWPM (modified Woody Plant medium) with $3.0 \mathrm{mg} / \mathrm{L} 2 \mathrm{iP}$ (N6-isopentenyladenine) or with $5.0 \mathrm{mg} / \mathrm{L} 2 \mathrm{iP}+0.1 \mathrm{mg} / \mathrm{L} \mathrm{NAA}$ (1-naphthaleneacetic acid).

In decade-long studies of in vitro regeneration, conducted by Boza and Altun (2013), the rate of shoot, root, and callus induction was examined on shoot tips, buds, and nodal cuttings; in vivo were taken from laurels located in the Turkish provinces of İzmir and Aydın. They used MS medium, DKW medium (Driver and Kuniyuki, 1984), and Heller and WPM (Woody Plant Medium) containing NAA, BAP, IBA; Kinetin plant, in different concentrations and combinations, could be used for micropropagation of the plant. They recommended that MS medium, having 0.3-4 mg/l BA and 0.5-5 mg/l NAA for the rooting of the micropropagated shoots. The rooting from woody plants is difficult due to the carry over effect of cytokinins (Huetteman and Preece., 1993). Although no study reported the rooting of bay laurel under in vitro conditions, the results are supported by the findings of Chourfi et al. (2014), Grigoriadou et al. (2002) on olive, Spahiu et al. (2013) on peach using IBA, and Sriskandarajah et al. (1982) on apples using $10 \mu \mathrm{M}$ NAA or $750 \mu \mathrm{M}$ IBA; all of them used IAA, IBA or NAA for rooting of woody shoots of different plants.

\section{Rooting and acclimatization}

The rooting and acclimation stages on plants affect the plants' development quality after acclimatization (McClelland, 1990). Adaptation studies of rooted bay laurel plants to external conditions are rare. The study confirms successful acclimatization of female bay laurel, when the humidity around the plants was gradually reduced to $50 \%$ and the first indications of rooting appeared after 4 weeks on MS medium containing $4.90 \mu \mathrm{M}$ IBA. The increase in the number of roots was very evident after 12 weeks, the results are supported by Grigoriadou et al. (2002), who acclimatized in vitro regenerated Chondrolia chalkidikis plants to a soil substrate containing peat moss and perlite (1:4) with $90 \%$ success. Binet et al. (2007) found that shoots of olive were successfully adjusted to external conditions after rooting (Nas, 2004) and reported that IBA applications in different concentrations to different hazelnut species have positive impacts on in vitro rooting. Khater and Benbouza (2019) have reported that the highest root numbers and lengths in Juniperus thurifera L. were produced on 1/2 MS medium supplemented with IBA and NAA (5.0mg $\mathrm{L}^{-1}$ each) and During transfer to acclimatization, rates of plant losses of $50 \%$ occurred. 


\section{Conclusion}

It is important to develop mass production technologies, suitable for different purposes, for non-wood forest products, especially bay laurel. For instance; in order to obtain bay laurel leaves and Essential Oils, generally female plants are preferred or male plants have the inside track to be grown due to being easier in terms of shaping and due to female plants being crumbled and causing pollution in landscape studies. With the results achieved from the study are, especially; it is considered that it would be possible to conduct early sex determination studies on perennial and diecious plants like bay laurel. it is assumed that optimization of in vitro micropropagation methods will help conscious commercial cultivation and easy breeding of bay laurel.

Acknowledgements. This study was supported by Agriculture, Forestry and Veterinary Research Grant Committee (TOVAG) of Scientific and Technical Research Council of Turkey (TUBITAK, Project No. 215O251) and Department of Agricultural Biotechnology Namik Kemal University, Tekirdag, Turkey. The author is pleased to thank Prof. Dr. Metin TUNA for flow cytometry analysis in his laboratory.

\section{REFERENCES}

[1] Arumuganathan, K., Earle, E. D. (1991): Estimation of nuclear DNA content of plants by flow cytometry. - Plant Molecular Biology Reporter 9: 229-241.

[2] Aydın Akbudak, M., Şakiroğlu, M., Tuna, M. (2018): Estimation of nuclear dna content and determination of relationship between altitude and genome size of usda turkish oat (avena spp.) collection. - Gesunde Pflanzen 70: 171-178.

[3] Bennett, M. D., Smith, J. B. (1976): Nuclear DNA amounts in angiosperms. - Phil. Trans. R. Soc. Lond 274: 227-276.

[4] Binet, M. N., Lemoine, M. C., Martin, C., Chambon, C., Gianinazzi, S. (2007): Micropropagation of olive (Olea europaea L.) and application of mycorrhiza to improve plantlet establishment. - In Vitro Cell.Dev.Biol.Plant 43: 473-478.

[5] Boza, A., Altun, Z. G. (2013): Propagation possibilites of bay laurel (Laurus nobilis L.) by Tissue Culture Method. - Ege Forestry Research Institute, İzmir.

[6] Cavusoglu, A., Sulusoglu, M. (2014): Effects of indole-3-butyric acid (IBA) and 1naphthaleneacetic acid (NAA) on rooting of female and male Laurus nobilis L. cuttings. International Journal of Biosciences 4: 206-216.

[7] Cepeda-Cornejo, V., Palomino, G., Méndez, I. (2012): Intersexual comparison of DNA content by flow cytometry and chromosome number in four dioecious chamaedorea palms from Mexico. - Caryologia 65: 263-270.

[8] Chaari Rkhis, A., Maalej, M., Drira, N., Alvaro, S. (2011): Micropropagation of olive tree (Olea europaea L.) oueslati. - Turk J Agric For 35: 403-412.

[9] Chourfi, A., Alaoui, T., Echchgadda, G. (2014): In vitro propagation of the Bay Laurel (Laurus nobilis. L) in Morocco. - South Asian Journal of Experimental Biology 4: 96103.

[10] Cobo, M. M., Gutierrez, B., Torres, M. D. (2019): Regeneration of mortio (Vaccinium floribundum Kunth) plants through axillary bud culture. - İn vitro cellular \& developmental biology-plant Volume 54: 112-116.

[11] Costich, D. E., Thomas, R., Meagher, E. J., Yurkow, A. (1991): Rapid means of sex identification in Silene latifolia by use of flow cytometry. - Plant Molecular Biology Reporter 9: 359-370.

[12] Darlington, C. D., Wylie, A. P. (1956): Chromosome atlas of flowering plants. - George Alien \& Unwin Ltd, London. 
[13] Demir, V., Gunhan, T., Yagcioglu, A. K., Degirmencioglu, A. (2004): Mathematical modelling and the determination of some quality parameters of air-dried bay leaves. Biosyst. Eng 88: 325-335.

[14] Dewir, Y. H., El-Mahrouk, M. E., Murthy, H. N., Paek, K. Y. (2015): Micropropagation of cattleya: improved in vitro rooting and acclimatization. - Hortic Environ Biotechnol 56: 89-93.

[15] Dhifi, W., Bellili, S., Jazi, S., Ben Nasr, S., El Beyrouthy, M., Mnif, W. (2018): Phytochemical composition and antioxidant activity of tunisian Laurus nobilis. - Pakistan journal of pharmaceutical sciences 31: 2397-2402.

[16] Doležel, J., Göhde, W. (1995): Sex determination in dioecious plants Melandrium Album and Melandrium Rubrum using high-resolution flow cytometry. - Cytometry19: 103-106.

[17] Driver, J. A., Kuniyuki, A. H. (1984): In vitro propagation of paradox walnut rootstock. HortSci 4:507-509.

[18] Ehrendorfer, F., Krendl, F., Habeler, E., Sauer, W. (1968): Chromosome numbers and evolution in primitive angiosperms. - Taxon 17(4): 337-353.

[19] Ercan, A. (1983): Defne yaprağı ve yağı ihracatının geliştirilmesi, ihracatı. - Geliştirme Etüd Merkezi, Ankara.

[20] Erkmen, S. (2009): The effects of cold stratification pretreatment on germination of tatar maple (Acer tataricum L.) seeds. - M.Sc. Dissertation-Ankara university, institue of sciences.

[21] Göker, Y., Acar, İ. (1983): Orman yan ürünlerinden (Laurus nobilis L.) Akdeniz Defnesi. - İ.Ü. Orman Fakültesi Dergisi 33: 124-140.

[22] Grigoriadou, K., Vasilakakis, M., Eleftheriou, E. P. (2002): In vitro propagation of the greek olive cultivar "Chondrolia Chalkidikis. - Plant Cell, Tissue and Organ Culture 71(1): 47-54.

[23] Huetteman, C. A., Preece, J. E. (1993): Thidiazuron: a potent cytokinin for woody plant tissue culture. - Plant Cell, Tissue and Organ Culture 33: 105-119.

[24] Khater, N., Benbouza, H. (2019): Preservation of Juniperus thurifera L.: a rare endangered species in Algeria through in vitro regeneration. - Journal of forestry research 30: 177-86.

[25] Kilic, A., Hafizoglu, H., Kollmannsberger, H., Nitz, S. (2004): Volatile constituents and key odorants in leaves, buds, flowers, and fruits of (LaurusnobilisL). - Journal of Agricultural and Food Chemistry 52: 1601-1606.

[26] Konukçu, M. (2001): Ormanlar ve ormancılığımız. - Ankara Devlet Planlama Teşkilatı Yayınları, Ankara.

[27] Lanzara, P., Pizetti, M. (1989): Les arbres. - Nathan, Milan.

[28] Maarten, J. M., Christenhusz, J. W. B. (2016): The number of known plants species in the world and its annual increase. - Phytotaxa 261(3): 201-217.

[29] McClelland, M. T., Smith, M. A. L., Carothers, Z. B. (1990): The effects of in vitro and ex vitro root initiation on subsequent microcutting root quality in three woody plants. Plant Cell Tissue and Organ Culture 23: 115-123.

[30] Murashige, T., Skoog, F. (1962): A revised medium for rapid growth and bioassays with tobacco tissue cultures. - Physiol Plant 15: 473-497.

[31] Nas, M. N. (2004): Inclusion of polyamines in the medium improves shoot elongation in hazelnut (Corylus avellana L.) micropropagation. - Turkish Journal of Agriculture and Forestry 428: 189-194.

[32] Noirot, M., Barre, P., Louarn, J., Duperray, C., Hamon, S. (2002): Consequences of stoichiometric error on nuclear DNA content evaluation in Coffea liberica var. dewevrei using DAPI and propidium iodide. - Ann. Bot 89: 385-389.

[33] Panza, E., Tersigni, M., Iorizzi, M., Zollo, F., De Marino, S., Festa, C., Napolitano, M., Castello, G. (2011): Lauroside B, a megastigmane glycoside from Laurus nobilis L. (bay laurel) leaves, induces apoptosis in human melanoma cell lines by inhibiting NF- $\mathrm{KB}$ activation. - Journal of Natural Products 74: 228-33. 
[34] Parlar, E. (2017): Sex determınation in Laurus nobilis L. using flow cytometry method. M.Sc. Dissertation, Tekirdağ Namık Kemal university.

[35] Sari, A., Oğuz, B., Bilgiç, A. (2006): Breaking seed dormancy of laurel (Laurus nobilis L.). - New Forests 31: 403-408.

[36] Savas Tuna, G., Duyu, G., Uzun, K., Yucel, G., Tuna, M. (2017): Determination of nuclear DNA content and ploidy of Hypericum perforatum $L$. accessions collected from western Turkey. - Journal of agricultural sciences 23: 395-403.

[37] Snedecor, G. W., Cochran, W. G. (1982): Statistical methods. - The Iowa State University Press, Iowa.

[38] Souayah, N., Khouja, L. M., Khaldi, A., Rejeb, N. M., Bouzid, S. (2002): Breeding Improvement of Laurus nobilis L. by Conventional and In vitro Propagation Techniques. - Journal of Herbs Spicies \& Medicinal Plants 9: 101-105.

[39] Spahiu, E., Hodaj, B., Rama, P. (2013): The influence of season collection of explants on micropropagation of peach rootstock GF-677. - Journal Agriculture Sci 12: 15-18.

[40] Sriskandarajah, S., Mullins, M. G., Nair, Y. (1982): Induction of adventitious rooting in vitro in difficult to propagate cultivars of apple. - Plant Science Letters 24: 1-9.

[41] Stanica, F., Standardi, A., Hoza, D., Tudor, T. A. (1992): Studies on micropropagation of laurel (Laurus nobilis L.). - Seria B, Horticultura 35: 83-90.

[42] Şenyay, D. (2008): Researches on in vitro regeneration of mastic tree (pistacia lentiscus l.). - M.Sc. Dissertation, Ege university.

[43] Tanrıverdi, H. (1993): Defne meyvası sabit yağının esktraksiyon verimi ve kalitesinin belirlenmesi üzerine bir araştırma. - FABAD-J, Pharm.Sci 18: 107-113.

[44] Tuna, M., Vogel, K. P., Arumuganathan, K., Gill, K. S. (2001): DNA content and ploidy determination of bromegrass germplasm accessions by flow cytometery. - Crop Sci 41: 1629-1634.

[45] Tuna, M. (2016): Flow cytometry and use in agricultural research. II. Flow Cytometry and Use in Agricultural Research. - Handbook, Tekirdag.

[46] Vagera, J., Paulíková, D., Doležel, J. (1994): The development of male and female regenerants by in vitro androgenesis in dioecious plant (Melandrium albüm). - Annals of Botany 73: 455-459.

[47] Villar, L. (1986): Lauraceae. - In: Castroviejo. Flora Iberica. Madrid: Real Jardin Botanico, C.S.I.C. 199- 200.

[48] Zonneveld, B. J., Leitch, M. I. J., Bennett, M. D. (2005): First nuclear DNA amounts in more than 300 angiosperms. - Annals of Botany 96: 229-244. 